\begin{tabular}{ccc}
\hline International Journal of Engineering \& Technology, $7(4.1)(2018) 90-93$ \\
SPC & Website: www.sciencepubco.com/index.php/IJET \\
Research paperer & Technology \\
\hline
\end{tabular}

\title{
The Effectiveness of MRP System to Forecast the Accuracy Inventory Requirement
}

\author{
Hairul Rizad Md Sapry1*, Lorio L' wiey Anak Tawi ${ }^{2}$, Abd Rahman Ahmad ${ }^{3}$, Shathees Baskaran ${ }^{4}$ \\ ${ }^{1}$ Senior Lecturer, Universiti Kuala Lumpur, Malaysia Institute of Industrial Technology (UniKL MITEC) \\ ${ }^{2}$ Assistance researcher, Universiti Kuala Lumpur, Malaysia Institute of Industrial Technology (UniKL MITEC) \\ ${ }^{3}$ Senior Lecturer, Universiti Tun Hussion Onn (UTHM) \\ ${ }^{4}$ Senior Lecturer, Universiti Teknologi Malaysia (UTM) \\ *Corresponding author E-mail: hairulrizad@unikl.edu.my
}

\begin{abstract}
The implementation of MRP systems play a crucial role in today's manufacturing process in providing valuable information not only to both marketing and manufacturing team, but the organization as a whole. Yet, MRP system does not possess the capability of doing everything. There are few limitations within MRP system in relation to flexibility and adaptability to the changes of the external environment. The objective of the study is to investigate the capability of MRP system in providing an accurate forecast for the inventory requirement. The study was conducted through a qualitative case study approach by analyzing historical data of a single multinational organization which is currently implementing MRP system in managing their inventory. Few supply chain performance indicators were applied to measure the effectiveness of MRP system in managing the inventory process. The result revealed that MRP system under investigation is the central engine for managing inventory and ensuring customer service. However, MRP system require valid and reliable data optimized by a set of pre-defined parameters to run effectively with possible interface with other supporting software. This study suggests other supporting software such as Stock Model to be interfaced with the MRP system for greater flexibility and adaptability in respond to foreseeable or unforeseeable external changes.
\end{abstract}

Keywords: Supply chain management; Inventory management; Material resource planning; Stock model.

\section{Introduction}

In the era of Industry 4.0, competitive pressures are forcing manufacturing companies to continually seek new ways to manage their production capabilities more effectively owing to the growing uncertainty in the market and changing customers' requirements to make their production and logistics processes more flexible. The implementation of Material Resource Planning (MRP) has become a cornerstone to the modern manufacturing process where the requirement for the MRP is so engrained in the manufacturing industry. The major objectives of MRP system are threefold: i. ensure the availability of materials, components, and products for planned production and for customer delivery; ii. maintain the lowest possible level of inventory; and iii. plan manufacturing activities, delivery schedules, and purchasing activities to meet the changing dynamics of the marketplace. In line with the development of the technology, MRP has been designed to be more robust and complex to meet the changing market requirements. Growing complexity of the application has become a great challenge to the users when compared to existing knowledge and understanding among them. In certain situations, MRP has been seen as the ultimate method to forecast inventory requirement. However, in real world practices, there are limitations within MRP system in handling and previous simulation studies have shown that MRP has difficulties in handling variations in demand and lead times which was evident in various past studies [1]. Therefore, the roll out of the application in the organization facilitated by expert consultants have been identified as one of the key success factors for application implementation apart from having an appropriate set of parameters for execution with an ultimate aim of enabling close to accurate forecasting capabilities.

\section{Function of Material Resources Planning (MRP)}

MRP is a system that functions as a material controller that attempts to keep adequate inventory levels to assure that required materials are available when needed. MRP is applicable in situations of multiple items with complex bills of materials. However, it is not efficient for continuous processes that are tightly linked. MRP is especially suited to manufacturing settings under deterministic environment. Unfortunately, in practice, most of the production systems vary in predicting the forecast. Therefore, under demand uncertainty, MRP will combine the consideration of lot sizing, safety stock and safety lead time in the calculation. A poor quality of data entered into the system could risk the company to experience high stock variation, overstock situations, and supply shortage in meeting customer demand. Such conditions will impact the inventory performance, service level performance, and may result at high expenses and wastages.

\section{MRP and the Problems}

Although most MRP vendors claim that the system's approach fits all company's requirements in all industries [2], issues characterized by unacceptable inventory performance, unacceptable service- 
level performance and high expedite-related expenses are readily known to the practitioners prior to formal studies in these areas. The resulting problems taken from [3], and [4,5] are shown in the following Table 1 .

Table 1: Common MRP-related problems

\begin{tabular}{|c|c|c|}
\hline Author & $\begin{array}{c}\text { Shortcoming of } \\
\text { MRP }\end{array}$ & Issues \\
\hline $\begin{array}{l}\text { Goldratt et al } \\
\text { (2009) }\end{array}$ & $\begin{array}{l}\text { Forecast and } \\
\text { MPS }\end{array}$ & $\begin{array}{l}\text { Misalignment between fore- } \\
\text { casted demand and real customer } \\
\text { orders. Lead to stock out situa- } \\
\text { tion or high holding cost. }\end{array}$ \\
\hline $\begin{array}{c}\text { (Wijngaard, } \\
\text { 2007). }\end{array}$ & Full BOM runs & $\begin{array}{l}\text { MRP pegs down the full BOM to } \\
\text { the lowest hierarchy level inde- } \\
\text { pendently for each stock-keep- } \\
\text { ing unit (SKU) that can easily } \\
\text { change triggered by a small } \\
\text { change at an upper level material }\end{array}$ \\
\hline $\begin{array}{l}\text { (Smith and } \\
\text { Ptak, 2013) }\end{array}$ & $\begin{array}{l}\text { Manufacturing } \\
\text { order release }\end{array}$ & $\begin{array}{l}\text { Rely to Lead time criteria only } \\
\text { to make a decision without } \\
\text { checking the availability of the } \\
\text { parts }\end{array}$ \\
\hline $\begin{array}{l}\text { (Plenert, } \\
\text { 1999) }\end{array}$ & $\begin{array}{l}\text { Limited early } \\
\text { warning func- } \\
\text { tionality }\end{array}$ & $\begin{array}{l}\text { MRP creates work orders for } \\
\text { items that reach the configured } \\
\text { safety stock level. There is no } \\
\text { visibility of items that are near } \\
\text { this level or that might reach this } \\
\text { level in the near future due to } \\
\text { high customer demand. }\end{array}$ \\
\hline $\begin{array}{c}\text { Fisher } \\
(1997), \\
\text { Guillermo } \\
\text { Gallego } \\
(2010) \\
\end{array}$ & $\begin{array}{l}\text { Lead-time ambi- } \\
\text { guity }\end{array}$ & $\begin{array}{l}\text { MRP can use two different lead- } \\
\text { time types that can causes too } \\
\text { early or too late affecting the } \\
\text { work progress. }\end{array}$ \\
\hline $\begin{array}{l}\text { (Fisher, } \\
\text { 1997) }\end{array}$ & $\begin{array}{l}\text { Unresponsive de- } \\
\text { mand determina- } \\
\text { tion }\end{array}$ & $\begin{array}{l}\text { Demand volatility could cause } \\
\text { stock misalignment with market } \\
\text { needs due to the fixed character } \\
\text { of configuration in MRP system }\end{array}$ \\
\hline $\begin{array}{c}\text { (Ptak and } \\
\text { Smith, } 2008\end{array}$ & $\begin{array}{l}\text { Lacking priority } \\
\text { consideration }\end{array}$ & $\begin{array}{l}\text { MRP considers work orders for } \\
\text { stock replenishment, regular cus- } \\
\text { tomer demand and past due de- } \\
\text { mand as equal. This requires } \\
\text { continually observe and analyze } \\
\text { work orders and production } \\
\text { schedules, resulting in manual } \\
\text { priority changes. }\end{array}$ \\
\hline
\end{tabular}

\section{Research Methodology}

This study employed qualitative case study approach using observation where initial research on literature review was conducted to examine broader topics related to the subject. A case study approach was selected based on [6] suggestion that a case research design should be able uncover the issues underlying the current performance to determine the applicability of the subject research from the theoretical point of view which is an adequate approach of problem solving intended by this study [7]. In order to uncover these issues, a multinational manufacturing organization which is currently implementing MRP system known as Pronto Xi for material planning requirement was selected. This study aimed to determine the underlying reasons for the current performance and a simulation study designed to examine the impact of the implementation of MRP system over the inventory planning process. The evidence was gathered via semi-structured interviews, observation and an analysis of the existing MRP system performance. A manager who has experience in the implementation of MRP process was identified for the semi- structured interview process. A secondary data collection method was performed by analyzing various reports to collect data for the case study. The simulation model was created using Microsoft Excel and designed to compare with the MRP performance using representative parts data from the ERP system. The simulated results were then compared with the actual company per- formance and the case evidence was utilized in explaining the results and predicting the potential impact of adopting MRP. For simplicity and capacity reasons, a representative set of one SKU part out of the full product line of the company was selected

\subsection{Research flow}

This study attempted to investigate implementation of MRP system at a well-known multinational manufacturing organization involved in manufacturing of high quality writing instrument such as Ballpoint Pens, Fibre-Tips Pens, Gel Pens and Exam Grade Sharpener. To simplify the study, the researcher only investigated the Exam Grade Sharpeners (see figure 1) with delivery lead time of 112 days.

\begin{tabular}{r|l|}
\hline Item code: & 451848E \\
Description: & EXAM GRADE SHARPENER, BOX 48'S \\
\hline & TINTED BLACK \& RED \\
\hline 48 PCS $/$ BOX, 30 BXS / CTN \\
\hline
\end{tabular}

Fig. 1: SKU Exam Grade Sharpener

Figure 2 displays flow of the research. In order to investigate forecast accuracy of MRP system, data provided by the manufacturer for the period of July 2017 until Jun 2018 were examined. The accuracy of forecasting is examined based on the performance of actual demand and calculation of the Supply Chain Management indicator for inventory management. The indicator used are asset turnover and inventory days of supply.

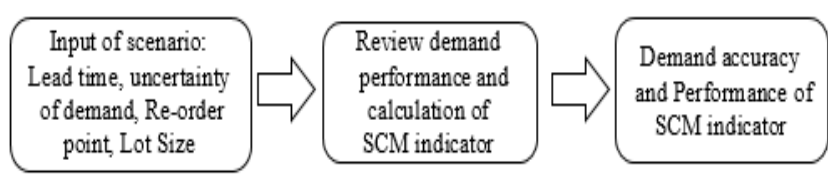

Fig. 2: Flow of the research

\subsection{Input parameter}

Table 2 indicate the purchased of SKU part for Exam Grade sharpener with a lead time of 112 days. The total lead time is used to indicate the total lead time demand as a basis for reorder point.

Table 2: Lead time

\begin{tabular}{cc}
\multicolumn{2}{c}{ Table 2: Lead time } \\
\hline Lead time (day) & Type \\
\hline 112 & Purchased \\
\hline
\end{tabular}

The lead time of 112 days is calculated starting from receipt of purchase order or work instruction by vendor up to arrival of shipment (FCL or LCL) at the manufacturer's warehouse. The findings indicated that all of the shipments arrived within the lead time of 112 days as reported in the production planning system. Nevertheless, the system also indicated that the safety stock parameters were not considered in the reorder point calculations. Based on the lead time assumptions and average demand forecast, a reorder point formula was developed to understand the purchase pattern for the part. Table 3 shows the formula developed for the reorder point calculations.

Table 3: Re-order point formula

\begin{tabular}{|l|r|}
\hline Average demand & 2,930 \\
\hline Lead time purchase & 112 \\
\hline $\begin{array}{l}\text { Lead time demand } \\
\text { (Average demand x Lead time) }\end{array}$ & 328,160 \\
\hline Safety stock & 0 \\
\hline $\begin{array}{l}\text { Reorder point } \\
\text { ( Lead time demand + safety stock) }\end{array}$ & 328,160 \\
\hline
\end{tabular}


The discussion revealed that a minimum lot size for every purchase is set at 77,760 pieces as required by the supplier.

The demand forecast in this study were populated based on the demand history and market intelligence information while the actual demand is based on the delivered order as shown in the table 4 .

Table 4: Forecast demand and actual demand

\begin{tabular}{|l|r|r|r|r|r|r|r|r|r|r|r|r|}
\cline { 2 - 13 } \multicolumn{1}{c|}{} & Jul & Aug & Sept & Oct & Nov & Dec & Jan & Feb & Mar & Apr & May & Jun \\
\hline Forecast & 95 & 80 & 100 & 80 & 60 & 45 & 80 & 90 & 140 & 50 & 161 & 87 \\
\hline Actual & 74 & 92 & 46 & 151 & 129 & 28 & 33 & 53 & 189 & 144 & 56 & 114 \\
\hline
\end{tabular}

Note : '000 (in thousand)

\section{Production Planning using MRP}

\subsection{Results and discussions}

From the input parameter of demand forecasts, lead time data, reorder point set up, and size of stock purchase, the researcher examines the performance of MRP system in providing an accurate forecast for the production planning. The first finding revealed that actual annual demand fall short by 41,631 units or 4 per cent of the demand forecasted. This indicates 96 per cent forecast accuracy which became the basis for the purchase of stock. However, the accuracy between months varies between -65 per cent to 189 per cent (see Table 5 and Figure 3).

The fluctuations in demand have influenced the inventory trend during end of the month, which stood between 115,889 pieces to 442,305 pieces with an average inventory level at 265,680 pieces. This level is lower compared to required reorder point for replenishing the order which was 328,160 pieces. The unstable level of inventory did not cause any stock out situation failing which could have impacted customer deliveries. However, the vicious fluctuation in the actual demand has impacted the inventory level as indicated by the asset turnover and Inventory days of supply (see Table 6). Ideally, the asset turnover for this case study should be at 3.68 times in the inventory days given a lead time of 112 days. The inconsistencies of inventory level may lead the company towards a stock out situation in case of sudden spike in demand or high inventory holding cost due to slow movement of the inventory.

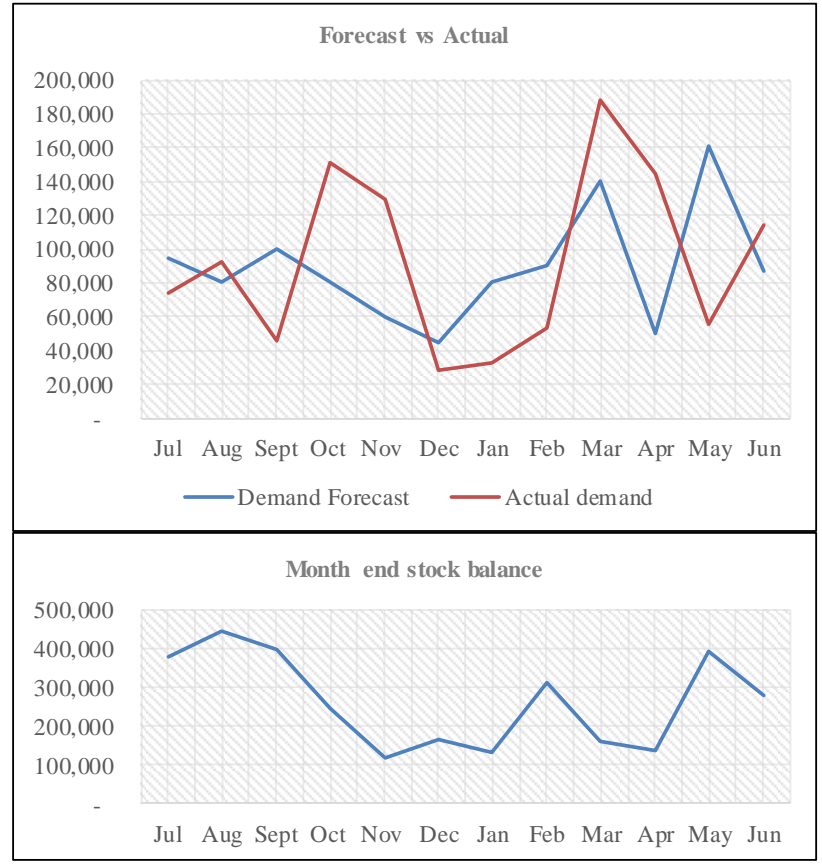

Fig. 3: Forecast vs actual, month end stock balance

In terms of inventory of supply performance, 6 occasions (2017 Oct and Nov, 2018 - Jan, March, April, June) recorded below the ideal lead time of 112. This situation exposes the company to stock out situation in case of delay in the purchase shipment. While 4 occasions (2017 - Sept and Dec, 2018 - Feb and May) recorded a high inventory of supply that indicates high holding cost during the period.

Seven (7) stock purchases occurred within the period of twelve (12) months in total of $1,010,880$ pieces. This purchase size was varying between 77,760 pieces to 312,480 pieces. This underutilization may incur additional cost to the company in terms of acquisition process and handling.

Table 5: Annual demand forecast

\begin{tabular}{|l|r|r|r|r|r|r|r|r|r|r|r|r|}
\cline { 2 - 14 } \multicolumn{1}{c|}{} & Jul & Aug & Sept & Oct & Nov & Dec & Jan & Feb & Mar & Apr & May & Jun \\
\hline Demand Forecast & 95 & 80 & 100 & 80 & 60 & 45 & 80 & 90 & 140 & 50 & 161 & 87 \\
\hline Purchase received & 78 & 155 & & & & 78 & & 233 & 35 & 120 & 312 & \\
\hline Actual demand & 74 & 92 & 46 & 151 & 129 & 28 & 33 & 53 & 189 & 144 & 56 & 114 \\
\hline Month end stock balance & 379 & 442 & 397 & 245 & 116 & 165 & 133 & 313 & 159 & 134 & 391 & 276 \\
\hline Total Inventory & 61 & 70 & 63 & 39 & 19 & 26 & 21 & 50 & 25 & 21 & 63 & 44 \\
\hline Total production cost & 16 & 18 & 9 & 30 & 26 & 6 & 7 & 11 & 38 & 29 & 11 & 23 \\
\hline Total sales & 19 & 23 & 11 & 37 & 32 & 7 & 8 & 13 & 48 & 36 & 14 & 29 \\
\hline Asset Turns & 3.68 & 3.90 & 2.15 & 11.57 & 20.95 & 3.21 & 4.62 & 3.17 & 22.21 & 20.15 & 2.69 & 7.74 \\
\hline Inventory days of supply & 113 & 117 & 212 & 39 & 22 & 142 & 99 & 144 & 21 & 23 & 170 & 59 \\
\hline
\end{tabular}

Note : '000 (in thousand)

\section{Conclusions}

The aim of this study is to evaluate the capability of MRP system (i.e. Pronto Xi) in terms of forecasting accuracy to meet the inventory requirement and changes. Based on the given input parameter (e.g. demand forecasts, lead time data, demand variability, and size of stock purchase), the researcher has examined the forecast accuracy against the supply chain performance indicators for inventory management (i.e. asset turnover and inventory days of supply).
The result shows that despite the capability of MRP system to suggest the schedule for stock purchase, the system itself is still lacking in terms of capability in response to the demand variability as a result of demand seasonality. It is observed that in certain months, the demand has spiked or dropped drastically against the demand forecasts. MRP in this study is seen to not respond effectively to the changes in the demand which resulted in the vicious fluctuation in the inventory forecast trend. This situation will cause instability in the inventory level by either exposing the company to a stock out situation or hurting the financial position of the organization due to high inventory holding cost. Similar findings were also found in the 
previous studies discussing inventory implications to the lack of response to demand determination [3].

As a solution for the shortcoming of MRP to the demand variability, it is suggested that the company shall use a stock model platform to address this gap in meeting and responding to the demand variability. The flexibility and adaptability of the stock model platform is suitable to address the issue of demand seasonality and other internal or external forces more effectively.

The stock model which operates based on the real time information is also suitable to improve any purchases with long lead time. The stock model also will offer the vendor a real time visibility of the changes in the planning and will help them to anticipate variations in the forecast numbers as compared to the current process. This will help to reduce the lead time in term of stock availability for the shipment and help to improve the responsiveness of the demand changes.

\section{Acknowledgement}

A special thanks to Lorio, AP Dr. Rahman, Dr. Shathess for their support and valuable assistance to complete this research.

\section{References}

[1] Kim K (2014), Material Resources Planning “(MRP): Will You Need MRP without the Customer?", Open Journal of Social Sciences, Vol.2, (2014), pp.256-261.

[2] Van Groenendaal W \& van der Hoeven H, (2018) "Best Practices in ERP: How good are they?", EIS 2008 Proceedings, Vol.1, No.1, p.14.

[3] Ihme M \& Stratton R (2015), "Evaluating Demand Driven MRP: a case based simulated study", International Conference of the European Operations Management Association, Neuchatel, Switzerland.

[4] Ptak CA \& Smith C (2008), "Beyond MRP", TOCICO International Conference, Las Vegas, Nevada.

[5] Ptak CA \& Smith C (2011), Orlicky's Material Requirements Planning, 3rd ed., McGraw-Hill, New York.

[6] Yin RK, Case Study Research (2009), 4th ed., Sage, Los Angeles.

[7] Bertrand JWM \& Fransoo JC (2002), "Operations management research methodologies using quantitative modelling", International Journal of Operations \& Production Management, vol.22, No.2, pp.241-264 